\title{
Mainstream Fourth Estate Gate
}

\author{
John Chabowski
}

So what do you want to see? The latest murder? How about an extraordinary piece on some shocking saying by an author? Look at the icon hogging the spotlight, eating your attention away in violent, furious nibbles like piranhas. By nibbling at your brain and consciousness, you become what we desire you to be: a plastic facsimile.

Icons shall be exalted as monarchs of media or mowed down as high grass hooligans. Your attention span doesn't last that long so the sound bites are ten seconds long. Plus we only have so much time to show all the headlines, for we work for advertising revenue. What will be the lead story today? A politician with an outspoken quote? Or a celebrity promoting a product preying on your vanity, though vehemently denies that he or she is not there to sell it?

Headlines don't whisper, they bark and hiss at you from your screen or newspaper. Shock is what we the gatekeepers of the Fourth Estate wish to elicit from you, the public, and you then become paralysed with active hypnosis.

Focus, focus, focus on the flashing lights for don't you love to see an accident? Are you not exhibitionists? Don't deny it because you love to watch. Wait, don't change the channel. Here's a story on the latest catastrophe from an exotic land. See those humans flee, aren't you happy that it's not you? 


\section{Mainstream Fourth Estate Gate}

Isn't it all the same even if it is another day? The news variables are simple enough, though we don't want you to think about it. We are the gatekeepers, and our editors and producers are the collective of St. Peter. We have the keys to perception, and we possess the only means to heaven and hell.

It's a farce that some believe in a liberal or conservative conspiracy in mass media. Really, are you that gullible of a public? You know what matters? Do you really want to know? Come close to the screen and we'll tell you. Profit from advertisers, our ratings, that our shareholders receive their dividends on their holdings: that matters to us, the mainstream Fourth Estate.

The Internet has democratised the news, and that irritates us so much. That's why we've infiltrated the web with our own $\mathrm{Os}$ and $1 \mathrm{~s}$, consolidating the news before you login to your e-mail and search in Google for news. What do you expect from us? We must go with the times, and we've had to compete with publically funded news and all these internet sources.

We catch you in the morning, afternoon and evening. Our news comes at a price, buying people off to give us their exclusive story first for the best ratings. Be it a murder, accident, politicians kissing babies or visiting a factory, or some press conference with a famous star: we'll be there to fill that hole of unneeded information. We're here to fill that gap as cement in a newly built condo of commodification. 


\section{John Chabowski}

So what do you want to see? A current affairs program under the guise of actual content and cash for commentary? The latest sneak-peek from our primetime programming in our morning show? Idolisation of your heroes and hegemonic influences and what they're wearing? The latest shocker from our shores?

It doesn't matter. We, the mainstream Fourth Estate, shall provide you with the wonderful spectacles of life so you can tell others, replicating and referring others to our news and privately funded messages. Shhh, don't tell anyone though.

Why do you flip the TV on to us? Because we are the known, giving you the soft velvet hegemony from the predictable agents. Don't turn away from us. Wait, where are you going? Stop, you'll miss the sports and weather. Stay tuned also for our primetime investigation program, the supplemental to our regular broadcast. You can always trust us, the mainstream Fourth Estate, for would we lie to you?

Headlines barrage you each day, leaping from our wellknown alley of mainstream media to enforce the status quo of sensationalism. The news is just entertainment disguised in sheep's clothing as an objective perception of reality. We ignore the stories of the lesser-known and the positive outcomes for sex, violence and conflicts sells, especially to our stockholders.

We are the mainstream Fourth Estate, your daily aphrodisiac for you huddled masses. Trust us, watch us, ingest us, follow us, tune in to us. You know you want to, you know you need it, you know you wake up for it, you know you want it. 